\title{
Simulation Analysis of Machetang Wire Nets Concrete Inverted Siphon Dongyu $\mathrm{Ji}^{\mathrm{a}}$

\author{
Hunan Urban Construction College, Xiangtan, Hunan Province 411101, P.R. China \\ ahnjdy@126.com
}

Keywords: Inverted siphon, Simulation analysis, Analysis path, Circumferential stress

\begin{abstract}
This paper adopts finite element software to carry out structure design and force analysis for Machetang wire nets concrete inverted siphon engineering. Researching distribution laws of stress and deformation for inverted siphon's typical sections and paths under various cases in construction and operating process. Research results provide reliable theory references for safe operation of Machetang wire nets concrete inverted siphon engineering.
\end{abstract}

\section{Project summary}

Machetang inverted siphon engineering is located east main canal of Baifeng reservoir irrigation, which is located Yiwu county in Zhejiang province. Inverted siphon engineering distances upstream of the canal is $9.5 \mathrm{~km}$, the basin area that is controlled by inverted siphon engineering is $16000 \mathrm{mu}$. The engineering adopts bridge-type inverted siphon structure form, inverted siphon is precast wire nets concrete pipe structure, concrete strength grade of inverted siphon is C30. Juncture of inverted siphon adopts socket type joint, rubber ring sealing is adopted. Inverted siphon's flow rate is $1.1 \mathrm{~m}^{3} / \mathrm{s}$, flow velocity is $2.14 \mathrm{~m} / \mathrm{s}$, roughness is 0.012 , inner diameter of reinforced concrete pipe is $0.8 \mathrm{~m}$, wall thickness is $0.1 \mathrm{~m}$. Inverted siphon's overall length is $155.3 \mathrm{~m}$, head loss is $1.5 \mathrm{~m}$. Inverted siphon's minimum level is $16.5 \mathrm{~m}$, design level is $21 \mathrm{~m}$, maximum level is $22.4 \mathrm{~m}$.

\section{Structure Force Calculation}

Model Parameters. Concrete strength grade of Machetang inverted siphon pipe is C30, elastic modulus $\mathrm{E}_{1}=30 \mathrm{GPa}^{[1]}$, Poisson ratio $\mu_{1}=0.167$, density $\gamma_{1}=24 \mathrm{kN} / \mathrm{m}^{3}$. Concrete strength grade of arch and subcrust is C20, elastic modulus $E_{2}=25.5 \mathrm{GPa}$, Poisson ratio $\mu_{2}=0.167$, density $\gamma_{2}=24$ $\mathrm{kN} / \mathrm{m}^{3}$. Inverted siphon's pier adopts grouting stone-laying, elastic modulus $\mathrm{E}_{3}=17 \mathrm{GPa}^{[2]}$, Poisson ratio $\mu_{3}=0.27$, density $\gamma_{3}=26 \mathrm{kN} / \mathrm{m}^{3}$.

Element Selection and Model Size. Force analysis is proceeded for Machetang inverted siphon, inverted siphon pipe, arch, subcrust and pier are divided by eight nodes isoparametric block element. The element is often applied to three-dimensional model of entity structure, it has eight nodes, each node has three translational degree of freedoms ${ }^{[3]}$. And wire nets concrete pipe adopts to overall rebar role model, it simulates wire nets role through defining reinforcement ratio in all directions ${ }^{[4]}$. When inverted siphon structure calculation model is established, it simulates mainly inverted siphon horizontal segment, horizontal segment's water pressure is maximum. Calculation model size is listed below, calculation model along inverted siphon pipe is $18 \mathrm{~m}$, transverse of inverted siphon pipe is $4.2 \mathrm{~m}$, vertical direction is $9.8 \mathrm{~m}$. The simulation range of whole calculation model is $18 \mathrm{~m} \times 4.2 \mathrm{~m} \times 9.8 \mathrm{~m}$. Element division of inverted siphon structure is shown in Fig.1.

Calculation Cases. Considering mechanical characteristics of Machetang inverted siphon structure in construction and operating process, researching four cases as follows ${ }^{[5]}$. Case 1 , inverted siphon pipe weight; case 2, inverted siphon pipe weight and minimum level $(16.5 \mathrm{~m})$; case 3 , inverted siphon pipe weight and design level (21m); case 4, inverted siphon pipe weight and maximum level (22.4m). 


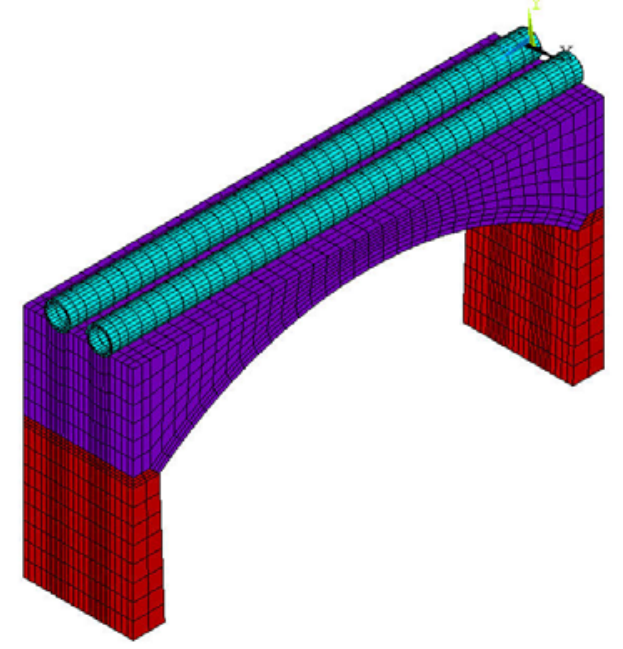

Fig.1 Element division of inverted siphon structure

\section{Calculation Results Analysis}

Paths Selection. In order to know clearly stress and deformation of inverted siphon structure, from the middle section of inverted siphon, from top of inverted siphon pipe to bottom of pipe, choosing respectively seven calculation points along with clockwise on internal and outside surface of inverted siphon pipe. Two analysis paths are confirmed, Path 1, internal surface of inverted siphon pipe, Path 2, outside surface of inverted siphon pipe. Stress and deformation distribution of these analysis paths are provided in the paper.

Stress Analysis. Under various cases, calculation points circumferential stress distribution of inverted siphon pipe's analysis paths in construction and operating process is listed in the table 1.

Table 1. Calculation points circumferential stress values of analysis paths under various cases(MPa)

\begin{tabular}{ccccccccc}
\multicolumn{2}{c}{ Calculation Point } & (1) & (2) & (3) & (4) & (5) & (6) & (7) \\
\hline \multirow{2}{*}{ Case 1 } & Path 1 & -0.05 & -0.04 & 0.01 & 0.05 & 0.03 & -0.01 & -0.03 \\
& Path 2 & 0.01 & 0.01 & -0.01 & -0.02 & 0.02 & -0.01 & -0.01 \\
\multirow{2}{*}{ Case 2 } & Path 1 & 0.73 & 0.72 & 0.72 & 0.73 & 0.72 & 0.52 & 0.34 \\
& Path 2 & 0.56 & 0.57 & 0.58 & 0.61 & 0.31 & 0.22 & 0.21 \\
Case 3 & Path 1 & 0.94 & 0.92 & 0.92 & 0.91 & 0.91 & 0.66 & 0.44 \\
& Path 2 & 0.71 & 0.73 & 0.74 & 0.78 & 0.39 & 0.28 & 0.27 \\
Case 4 & Path 1 & 1.00 & 0.99 & 0.98 & 0.97 & 0.97 & 0.71 & 0.48 \\
& Path 2 & 0.76 & 0.78 & 0.80 & 0.83 & 0.41 & 0.30 & 0.29
\end{tabular}

We can see from table 1, under inverted siphon pipe weight, circumferential stress values of inverted siphon pipe is very small, compressive stress appears in inverted siphon pipe's top, and tensile stress of inverted siphon pipe's waist is smaller. Under internal water pressure, circumferential stress values of path 1 is greater than circumferential stress values of path 2 , this is mainly because circumferential stress of inverted siphon pipe's inside surface is greater than outside surface. On the same calculation path, from top of inverted siphon pipe to bottom of pipe, circumferential stress values of inverted siphon pipe decrease. This is mainly because inverted siphon weight and water pressure effect together, so producing such stress distribution law.

We obtain inverted siphon structure's cloud maps of first and third principal stress under case 3, cloud maps are shown from Fig.2 to Fig.3. Inverted siphon pipe and support's middle section's cloud maps of first and third principal stress under case 3 are shown from Fig.4 to Fig.5. 


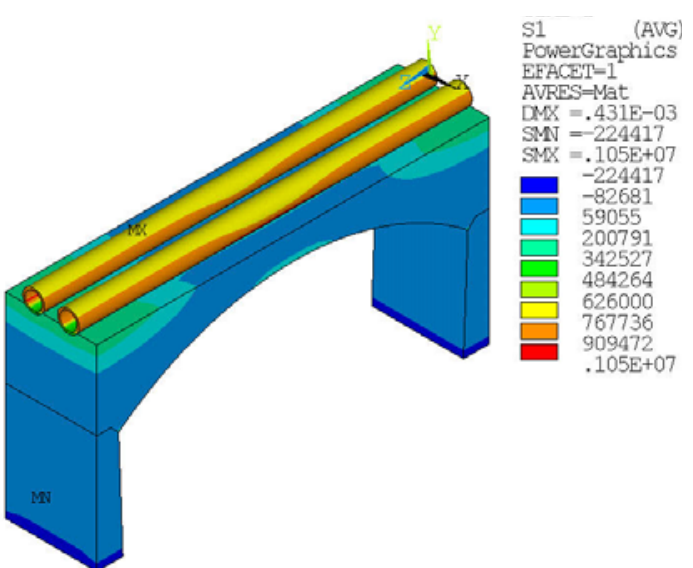

Fig.2. Inverted siphon structure's cloud map of first principal stress under case $3(\mathrm{~Pa})$

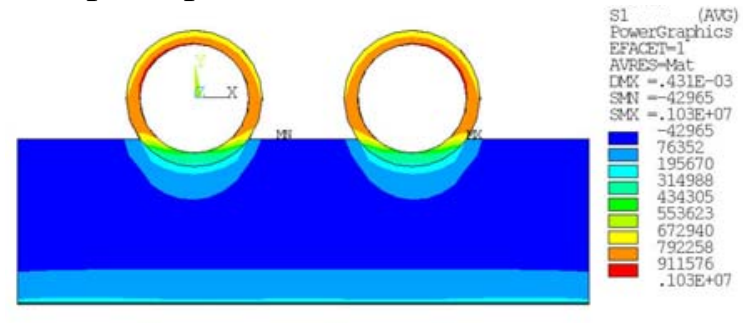

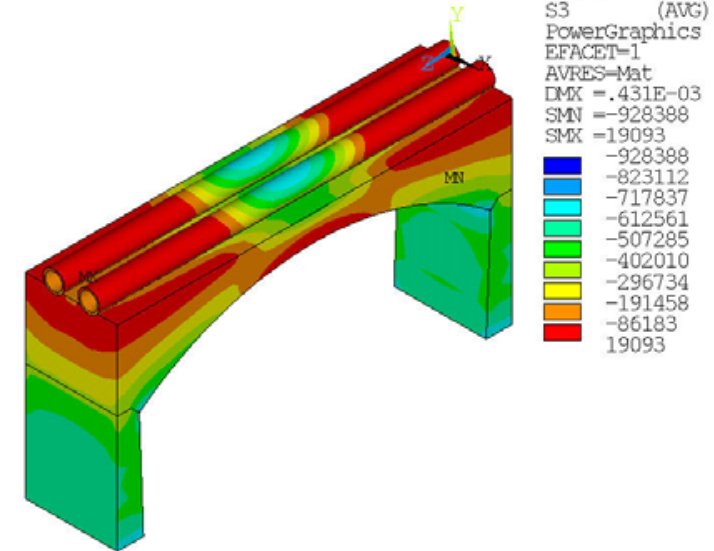

Fig.3. Inverted siphon structure's cloud map of third principal stress under case $3(\mathrm{~Pa})$

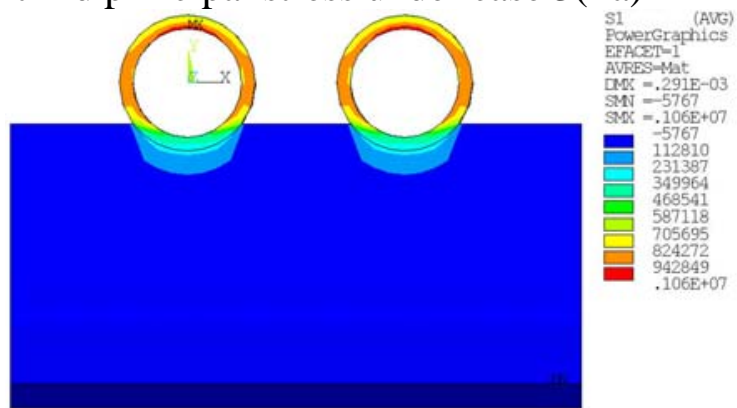

Fig.5. Inverted siphon's cloud map of one quarter of span section's first principal stress $(\mathrm{Pa})$

Fig.4. Inverted siphon's cloud map of one half of span section's first principal stress $(\mathrm{Pa})$ We can see from Fig.2 to Fig.3, inverted siphon structure's maximum first principal stress is 1.05MPa, it is located junction of inverted siphon pipe and subcrust. inverted siphon structure's maximum first principal stress inverted siphon pipe's middle section is 1.03MPa, it is located junction of inverted siphon pipe and subcrust, this is mainly because inverted siphon pipe weight and internal water pressure produces result. In Fig.5, maximum first principal stress of one quarter of span section is $1.06 \mathrm{MPa}$, it is located junction of inverted siphon pipe and subcrust, there appears certain stress concentration phenomenon.

Displacement Analysis. We obtain inverted siphon pipe's calculation points radial displacement values of path 1 under various cases in construction and operating process, radial displacement values are listed in the table 2.

Table 2. Calculation points radial displacement of path 1 under various cases $(\mathrm{mm})$

\begin{tabular}{cccccccc}
\hline Calculation Point & (1) & (2) & (3) & (4) & (5) & (6) & (7) \\
\hline Case 1 & -0.41 & -0.36 & -0.21 & -0.01 & 0.21 & 0.36 & 0.42 \\
Case 2 & -0.40 & -0.34 & -0.20 & 0.01 & 0.21 & 0.36 & 0.42 \\
Case 3 & -0.39 & -0.34 & -0.19 & 0.01 & 0.21 & 0.36 & 0.42 \\
Case 4 & -0.39 & -0.34 & -0.19 & 0.01 & 0.21 & 0.36 & 0.42 \\
\hline
\end{tabular}

We can see from table 2, inverted siphon pipe's radial displacement values are very small under various cases, under inverted siphon pipe weight, inverted siphon pipe's radial displacement is negative, this shows that inverted siphon pipe's top appears settlement displacement. Under internal water pressure, displacement of inverted siphon pipe's waist is very small, this shows that inverted siphon pipe happens vertical rigid displacement, but radial displacement of inverted siphon pipe is very small.

Through analysing displacement of Machetang inverted siphon, we obtain inverted siphon pipe's middle section's cloud maps of total displacement under case 1 and 3, cloud maps are shown from Fig.6 to Fig.7. 


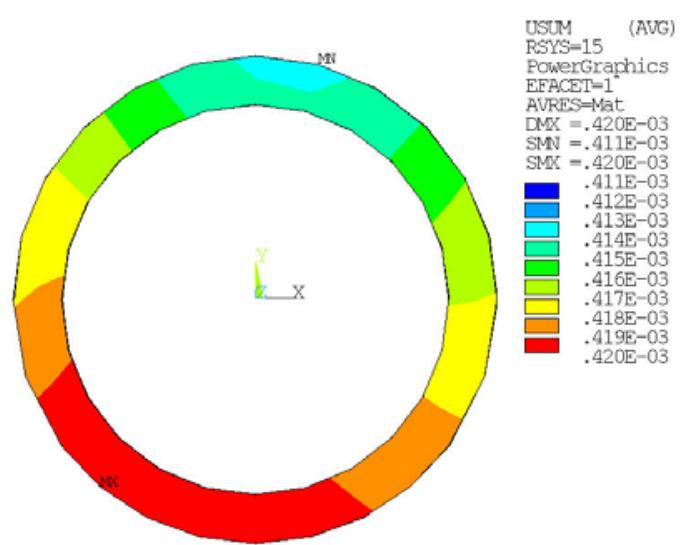

Fig.6. Inverted siphon pipe’s cloud map of total displacement under case $1(\mathrm{~m})$

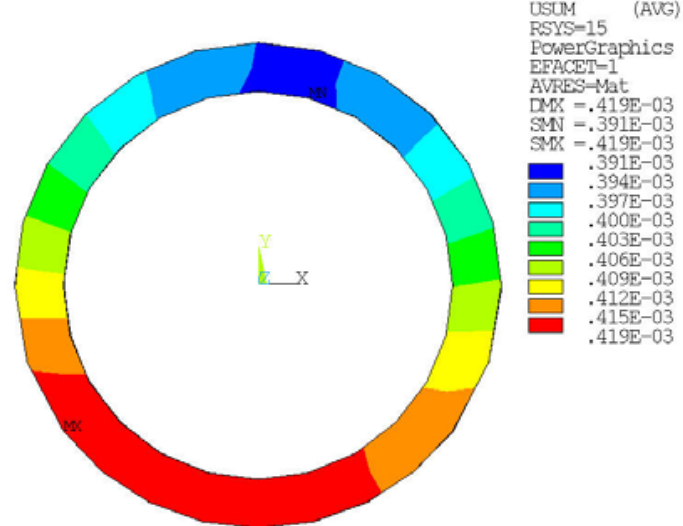

Fig.7. Inverted siphon pipe’s cloud map of total displacement under case $3(\mathrm{~m})$

We can see from Fig.6, inverted siphon pipe's maximum displacement is located near inverted siphon pipe's bottom, this is mainly because inverted siphon pipe produces overall settlement displacement under inverted siphon pipe weight. Displacement of inverted siphon pipe's bottom is maximum, maximum displacement is $0.42 \mathrm{~mm}$. In Fig.7, because the influence of inverted siphon weight and internal water pressure, maximum displacement of inverted siphon pipe is $0.42 \mathrm{~mm}$, it is located near inverted siphon pipe's bottom.

\section{Conclusion}

Analysis results show that, stress values of Machetang inverted siphon structure are smaller, the inverted siphon can meet strength requirements through the reinforcement of wire nets. Displacement of inverted siphon is very small, it can meet rigidity requirements. So Machetang inverted siphon structure is economic and reasonable, structure is safe and reliable.

\section{References}

[1] SL191-2008: Design Code for Hydraulic Concrete Structures(China Water Conservancy and Hydropower Press, China 2008)(in Chinese)

[2] Y.X. Zhang: Rock Mechanics(China Architecture and Building Press, China 2008)(in Chinese)

[3] B.F. Zhu: The Finite Element Method Theory and Applications(China Water Conservancy and Hydropower Press, China 2009)(in Chinese)

[4] J.J. Jiang, X.ZH. Lu, L.P. Ye: Finite Element Analysis of Concrete Structures(Tsinghua University Press, China 2005)(in Chinese)

[5] H.Y. Li, W.D. Tian, H.X Yan: Inverted Siphons(China Water Conservancy and Hydropower Press, China 2006)(in Chinese) 